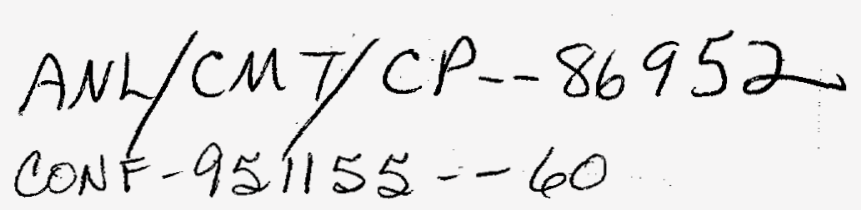

\title{
THE RELEASE OF CESIUM AND THE ACTINIDES FROM SPENT FUEL UNDER UNSATURATED CONDITIONS
}

\author{
P. A. Finn, J. C. Hoh, S. F. Wolf, S. A. Slater, and J. K. Bates \\ ARGONNE NATIONAL LABORATORY \\ Chemical Technology Division \\ 9700 South Cass Avenue \\ Argonne, IL 60439-4837

Submitted to

Materials Research Society Meeting

Boston, MA

November 27-December 1, 1995

The work was performed under contract to the Yucca Mountain Site Characterization Project sponsored by the DOE Office of Civilian Radioactive Waste Management at the Lawrence Livermore National Laboratory (contract number W-7405-ENG-48) and Argonne National Laboratory (contract number W-31-109-ENG-38).

\section{DISCLAIMER}

\begin{abstract}
This report was prepared as an account of work sponsored by an agency of the United States Government. Neither the United States Government nor any agency thereof, nor any of their employees, makes any warranty, express or implied, or assumes any legal liability or responsibility for the accuracy, completeness, or usefulness of any information, apparatus, product, or process disclosed, or represents that its use would not infringe privately owned rights. Reference herein to any specific commercial product, process, or service by trade name, trademark, manufacturer, or otherwise does not necessarily constitute or imply its endorsement, recommendation, or favoring by the United States Government or any agency thereof. The views and opinions of authors expressed herein do not necessarily state or reflect those of the United States Government or any agency thereof.
\end{abstract}




\section{DISCLAMMER}

Portions of this document may be illegible in electronic image products. Images are produced from the best available original document. 


\title{
THE RELEASE OF CESIUM AND THE ACTINIDES FROM SPENT FUEL UNDER UNSATURATED CONDITIONS
}

\author{
P.A. Finn, J.C. Hoh, S.F. Wolf, S.A. Slater, and J.K. Bates
}

Argonne National Laboratory, Chemical Technology Division, 9700 S. Cass, Argonne, IL 60439, U.S.A.

\section{ABSTRACT}

Tests designed to be similar to the unsaturated and oxidizing conditions expected in the candidate repository at Yucca Mountain are in progress with spent fuel at $90^{\circ} \mathrm{C}$. The similarities and the differences in release behavior for ${ }^{137} \mathrm{Cs}$ during the first 2.6 years and the actinides during the first 1.6 years of testing are presented for tests done with (1) water dripped on the fuel at a rate of 0.075 and $0.75 \mathrm{~mL}$ every 3.5 days and (2) in a saturated water vapor environment.

\section{INTRODUCTION}

Test conditions that are designed to be similar to the unsaturated and oxidizing conditions expected at the candidate repository at Yucca Mountain are in progress to evaluate the long-term behavior of two pressurized-water-reactor fuels at $90^{\circ} \mathrm{C}$. Tests with both fuels are done at drip rates of $0.75 \mathrm{~mL}$ every 3.5 days and $0.075 \mathrm{~mL}$ every 3.5 days, which correspond to the water flow expected in dry and wet climates at Yucca Mountain [1]. In addition, tests performed in a saturated water environment are ongoing with both fuels to evaluate the reactivity of fuel without liquid transport.

In this paper, we report the ${ }^{137} \mathrm{Cs}$ content in the liquid collected during the first 2.6 years of testing, a period during which both fuels showed visual evidence of reaction [2]. In addition, the actinide content during the first 1.6 years of testing is also reported. These data may indicate how different reaction processes control spent fuel reaction and how the amount of liquid present affects radionuclide release. The results for ${ }^{90} \mathrm{Sr},{ }^{99} \mathrm{Tc}$, and ${ }^{129} \mathrm{~T}$, which were used to determine the impact of gap and grain boundary release during the first 1.6 years of testing, will be published elsewhere [3].

\section{EXPERIMENTAL}

The two pressurized-water-reactor fuels used in these tests were ATM-103, which has a burnup value of $30(\mathrm{MW} \cdot \mathrm{d}) / \mathrm{kg} \mathrm{U}$ and a fission gas release of $0.25 \%$ [4], and ATM-106, which has a burnup of $43(\mathrm{MW} \cdot \mathrm{d}) / \mathrm{kg} \mathrm{U}$ and a fission gas release of $11 \%$ [5]. The fuels, $7-8.5 \mathrm{~g}$ samples, were in the form of large fragments with a geometric surface area of $2.1 \times 10^{-4} \mathrm{~m}^{2} / \mathrm{g}$. They were held in an unirradiated Zircaloy 4 holder. The groundwater, which came from well $\mathrm{J}-13$ near Yucca Mountain, was contacted at $90^{\circ} \mathrm{C}$ for 80 days with crushed core samples of Topopah Spring tuff and is designated EJ-13. The experimental configuration for the drip rate tests and the composition of the EJ-13 have been described elsewhere [6]. The vapor tests evaluate the reactivity of fuel under saturated water vapor pressure at $90^{\circ} \mathrm{C}$.

The higher drip rate $(0.75 \mathrm{~mL}$ every 3.5 days $)$ provides a continuous water flow pathway connecting all of the fragments for a short time after the twice weekly water injection. The lower drip rate provides a continuous water flow pathway for some of the spent fuel fragments. However, in both the drip tests and the vapor tests, the film of water that continuously contacts all of the fuel fragments provides a pathway for thin film transport. The surface area to volume (S/V) ratio for each 3.5 day period is $2240 \mathrm{~m}^{-1}$ for the high drip rate test and $22,400 \mathrm{~m}^{-1}$ for the low drip rate test. These values are based on the simplifying assumption that all of the water contacts all of the fuel, which is probably not true for the low drip rate tests.

The liquid in the test vessel was collected after intervals of approximately three to six months for the high drip rate tests and at least once a year for the low drip rate tests and the vapor tests. (The amount of liquid collected in a given sampling interval ranged from 14-30 mL for the high drip rate tests to $2-4 \mathrm{~mL}$ for the low drip rate tests.) The test vessel was acid stripped to 
collect adsorbed material. Aliquots of both liquids were characterized for actinide content using inductively coupled plasma-mass spectrometry (ICP-MS) in the scan mode with an indium internal standard. Mass interferences for the actinides were eliminated by using the reported $[4,5]$ isotopic composition of the two fuels to analyze the data. The error bars for the ICP-MS data are a maximum of $\pm 50 \%$ depending on radionuclide concentration. The ${ }^{137} \mathrm{Cs}$ content was obtained from gamma spectrometry data, which had an uncertainty of $<0.5 \%$ and a 1 sigma range of $3 \%$ for each measurement.

\section{RESULTS AND DISCUSSION}

We do not know the total extent of the spent fuel reaction since we have not analyzed the fuel fragments, measured the amount of material incorporated into precipitated alteration products or measured the amount adsorbed on the Zircaloy holder or on the spent fuel fragments. However, in order to interpret the data, we define "release fraction" as the sum of the amount of radionuclide in the test vessel and in the acid strip for each test interval divided by the amount of radionuclide in the spent fuel sample $(4,5)$. The cumulative release fraction is the sum of the-individual release fractions. We define "release rate" as the release fraction for a particular test interval divided by the days in the interval. (This release rate calculation assumes that all of the fuel surface area has reacted in a given time interval.) Using these definitions, we have examined the fractional release behavior of ${ }^{37} \mathrm{Cs}$ and the actinides for high drip rate, low drip rate and vapor tests.

Cs Release - The ${ }^{137} \mathrm{Cs}$ release fractions during successive test intervals for the drip tests are shown in Fig. 1. For both high and low drip rate tests, the ATM-103 fuel had a higher initial release than the ATM-106 fuel. However, after 1.6 years of testing, both fuels for successive sixmonth intervals had a constant release fraction of $1 \times 10^{-4}$ to $2 \times 10^{-7}$ in the high drip rate tests and $1 \times 10^{-7}$ to $3 \times 10^{-7}$ in the low drip rate tests. For the high drip rate test, the ${ }^{137} \mathrm{Cs}$ release rate at the 1.6-year interval was $2 \times 10^{-6}$ fraction/day. This latter rate is nearly two orders of magnitude smaller than the calculated matrix dissolution rate at $90^{\circ} \mathrm{C}, 9 \times 10^{-5}$ fraction/day, derived from Gray's work $[7,8]$ for ATM-103 and ATM-106 fuels. The high drip rate tests appeared to have sufficient liquid to transport dissolved material from the spent fuel to the bottom of the test vessel, as evidenced by the ${ }^{99} \mathrm{Tc}$ release rates at the interval at 1.6 years, $1 \times 10^{-4}$ and $6 \times 10^{-4} \mathrm{fraction} /$ day [3]. Since the ${ }^{137} \mathrm{Cs}$ release fractions for the high drip rate tests were smaller than the ${ }^{99} \mathrm{Tc}$ release fractions, this suggests that significant amounts of cesium are being incorporated into the alteration products formed on the spent fuel [2]. The magnitude of cesium incorporation was estimated by comparing the expected release from gap and exposed grain boundaries to the measured release fraction. Gray [7] reported a cumulative gap and grain boundary ${ }^{137} \mathrm{Cs}$ fraction of 0.0075 for ATM-103 and 0.035 for ATM-106. Our cumulative ${ }^{137} \mathrm{Cs}$ fractions after 1.6 years of reaction were 0.002 for ATM-103 and 0.003 for ATM-106, which correspond to 30 and $10 \%$, respectively, of the non-matrix ${ }^{137} \mathrm{Cs}$. Thus, we would expect that 70 to $90 \%$ of the non-matrix ${ }^{137} \mathrm{Cs}$ is incorporated into alteration products. (This is the minimum amount of ${ }^{137} \mathrm{Cs}$ incorporated into alteration products since $95 \%$ of the ${ }^{137} \mathrm{Cs}$ is located in the fuel matrix, and the fuel's appearance indicates that matrix dissolution has occurred.)

The volume of liquid introduced in the two drip tests differs by a factor of ten, but there is a 100 to 1000 -fold difference in the amounts of ${ }^{137} \mathrm{Cs}$ released. For the high drip rate tests, release should occur from all exposed surfaces and not be subject to transport limitations because during the injections the fuel surfaces are covered with liquid. For the low drip rate tests, evaporation from the fuel fragments is a concern since a drip pattern of precipitated material was observed on an ATM-106 fuel fragment. (The expected temperature gradient between the test vessel and the fuels due to decay heat is 1 to $2^{\circ} \mathrm{C}$, whereas, only a $0.6^{\circ} \mathrm{C}$ temperature gradient is needed in our apparatus to evaporate $0.075 \mathrm{~mL}$ of water in 3.5 days. ${ }^{1}$ ) Because the ATM-106 fuel has a higher decay heat than the ATM-103 fuel, 0.43 and $0.31 \mathrm{Ci} / \mathrm{g}$, respectively, the ATM-106 fuel fragments should have a larger water redeposition rate near the cooler Zircaloy-4 walls. (We have observed the growth of a whitish deposit on the ATM-106 fuel touching the Zircaloy wall in the vapor test.)

\footnotetext{
${ }^{1}$ We assumed that heat is transferred in the annular region of our apparatus. The equation used was $\left(T_{i}-T\right)=q_{k}\left(\ln \left(r_{0} / r_{i}\right)\right) /(2 \pi k l)$, where $r_{0}$ is the vessel diameter, $r_{i}$ is the Zircaloy diameter, $l$ is the Zircaloy height, $k$ is the air conductivity, and $q_{k}$ is the heat flux.
} 
The release fractions for the low drip rate tests are then a lower bound on the amount of radionuclides that can be transported under our unsaturated test conditions since the decay heat of the fuels would decrease as a function of time out of reactor.

For the vapor tests, the ${ }^{137} \mathrm{Cs}$ content was below detection limits $(30 \mathrm{pg})$ for the sampling intervals at 2 and 2.6 years. At early sampling intervals, the release fractions for the ATM-103 vapor test, $2 \times 10^{-7}$ to $5 \times 10^{-7}$, were similar to those for the corresponding low drip rate test. For the ATM-106 vapor test, the release fraction, $2 \times 10^{-6}$, was an order of magnitude greater than those for the corresponding low drip rate test. Release results for the low drip rate tests and the vapor tests would be expected to be different since there are no added EJ-13 ionic species in the vapor tests, species that enhance the formation of precipitated alteration phases in the drip tests. To account for the release of radionuclides in the vapor tests, a film transport pathway is suggested since a water film was present on the fuel surfaces at all times. Two other potential sources, which have been excluded, are dislodged fuel grains and external contamination during sampling. The design of the fuel holder [6], precludes any fuel grains larger than $10 \mu \mathrm{m}$ from reaching the test vessel. A spherical grain with this diameter contains $5 \times 10^{-9} \mathrm{~g}$ of ${ }^{238} \mathrm{U}$, which corresponds to $-7 \times 10^{-10}$ release fraction. Since the release fractions for low drip rate and vapor tests are one to three orders of magnitude larger than this, dislodged fuel grains do not appear to be a source. External contamination from hot cell manipulators is also not a source since ${ }^{137} \mathrm{Cs}$ was not detected in the liquid in a control test. However, we can not exclude aerosol transport.

Actinide Release - Releases in early test intervals may be dominated by release from the gap region or by dissolution of reaction products (impurities) present on the as-received fuel fragments. Therefore, we have attempted to separate these effects for the high drip rate tests by examining the release behavior after 1.3 years of reaction. We chose this interval since gap release was only observed during the first 0.8 years of reaction [3], and after 1.3 years of reaction based on ${ }^{129} \mathrm{I}$, the amount of ${ }^{238} \mathrm{U}$ released corresponded to the removal of at least 100 monolayers of fuel from the fragments if corrosion was uniform. Thus, at the 1.6-year interval, i.e., the interval between 1.3 and 1.6 years of reaction, differences between release fractions should be due to differences in bulk characteristics of the fuels.

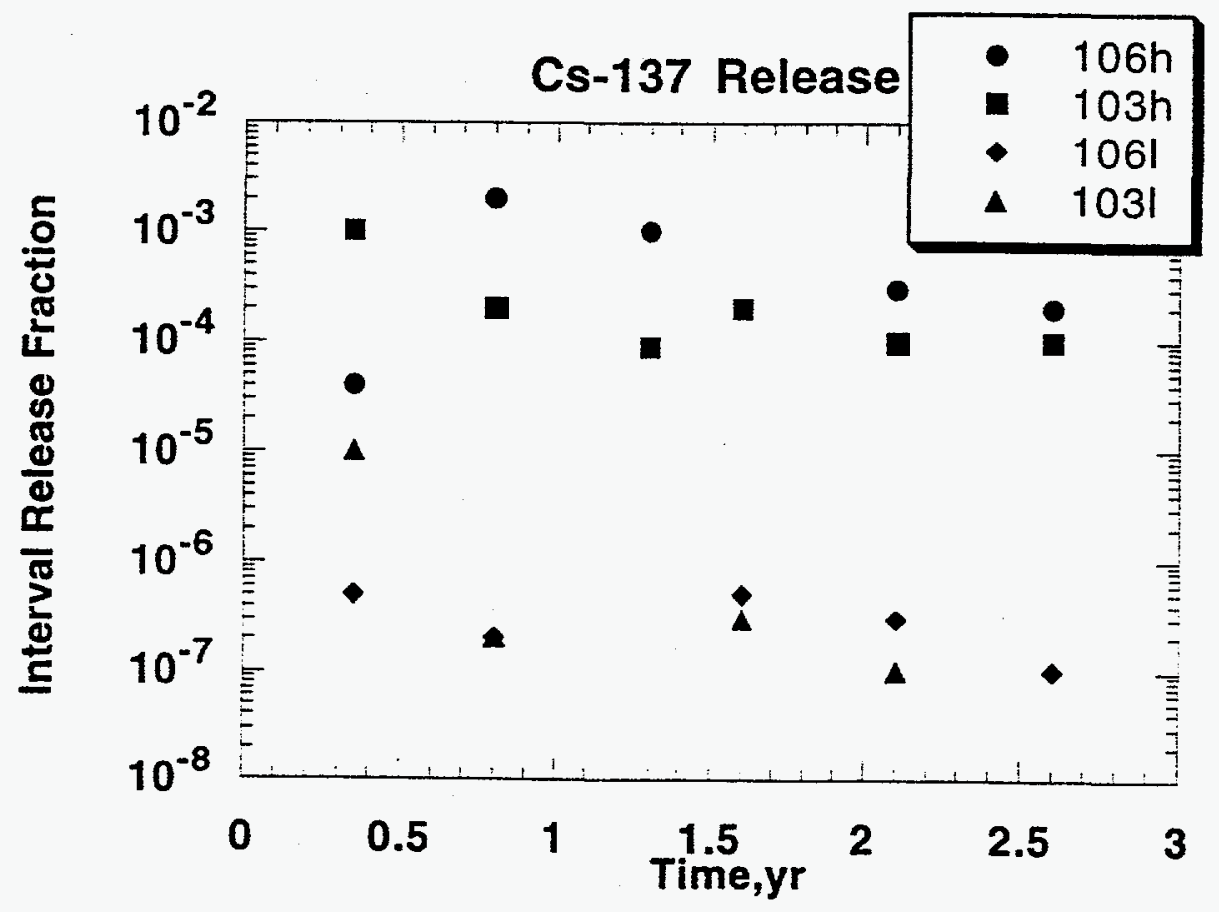

Figure 1. The ${ }^{137} \mathrm{Cs}$ Interval Release Fractions for High Drip Rate (h) and Low Drip Rate (l) Tests with ATM-103 and ATM-106 Fuel for the First 2.6 Years of Reaction. (At the 1.6-year interval, both $106 \mathrm{~h}$ and $103 \mathrm{~h}$ had the same release fractions. No ${ }^{137} \mathrm{Cs}$ was detected for 1031 at $2.6 \mathrm{yr}$. (The error bars for ${ }^{137} \mathrm{Cs}$ are $\pm 0.5 \%$.) 
The actinide release fractions for the high drip rate tests for each test interval are shown in Fig. 2 for ATM-103 and Fig. 3 for ATM-106. Table I lists the following data for both fuels for each actinide: (1) the release fraction for the interval between 1.3 and 1.6 years, the fraction ratio of individual species-to that of ${ }^{238} U$ for each fuel, and a comparison ratio between fuels of individual actinide fractions; and (2) similar data for the cumulative release fractions at 1.6 years of reaction to show the influence of reaction in earlier intervals.

The interval ratios of species-to uranium release fraction for both fuels were $2-3$ for ${ }^{24} \mathrm{Cm}$, 0.7-1 for ${ }^{241} \mathrm{Am}, 0.1-0.2$ for ${ }^{237} \mathrm{~Np}$, and 0.01-0.03 for ${ }^{239} \mathrm{Pu}$. Since these interval ratios are quite different than those for the cumulative fractions, this suggests that at early test intervals dissolution of impurities present on the bulk matrix may have dominated the results or that the sorption characteristics of the alteration products had an effect on the radionuclide release fractions.

The interval release fractions for ATM-106 were also less than those for ATM-103, although the cumulative ${ }^{238} \mathrm{U}$ and ${ }^{239} \mathrm{Pu}$ fractions were larger for ATM-106. This difference in the release fractions cannot be explained; however, the macrostructures of the two fuels may have a role. (The ATM-103 fuel contains large grains and small pores [3]. The ATM-106 fuel has both large and small grains and pores [4].)

Test Comparison - The cumulative ${ }^{137} \mathrm{Cs}$ and actinide releases for the high and low drip rate tests and the vapor tests are listed in Table $\Pi$, as are the cumulative release fractions reported by Wilson [9] for "semistatic" tests done on Turkey Point and ATM-101 fuels. The cumulative actinide release fractions for ${ }^{238} \mathrm{U},{ }^{239} \mathrm{Pu}$, and ${ }^{237} \mathrm{~Np}$ for the low drip rate tests were 10 to 100 times smaller than those for the high drip rate tests although those for ${ }^{24} \mathrm{Am}$ and ${ }^{244} \mathrm{Cm}$ were almost the same as those for the high drip rate tests. The cumulative actinide release fractions for the vapor tests were 100 times less than those for the low drip rate tests. Since for the vapor tests, no liquid water was introduced, the radionuclide release fractions may be attributed to film transport, although film transport calculations are necessary to substantiate these conclusions.

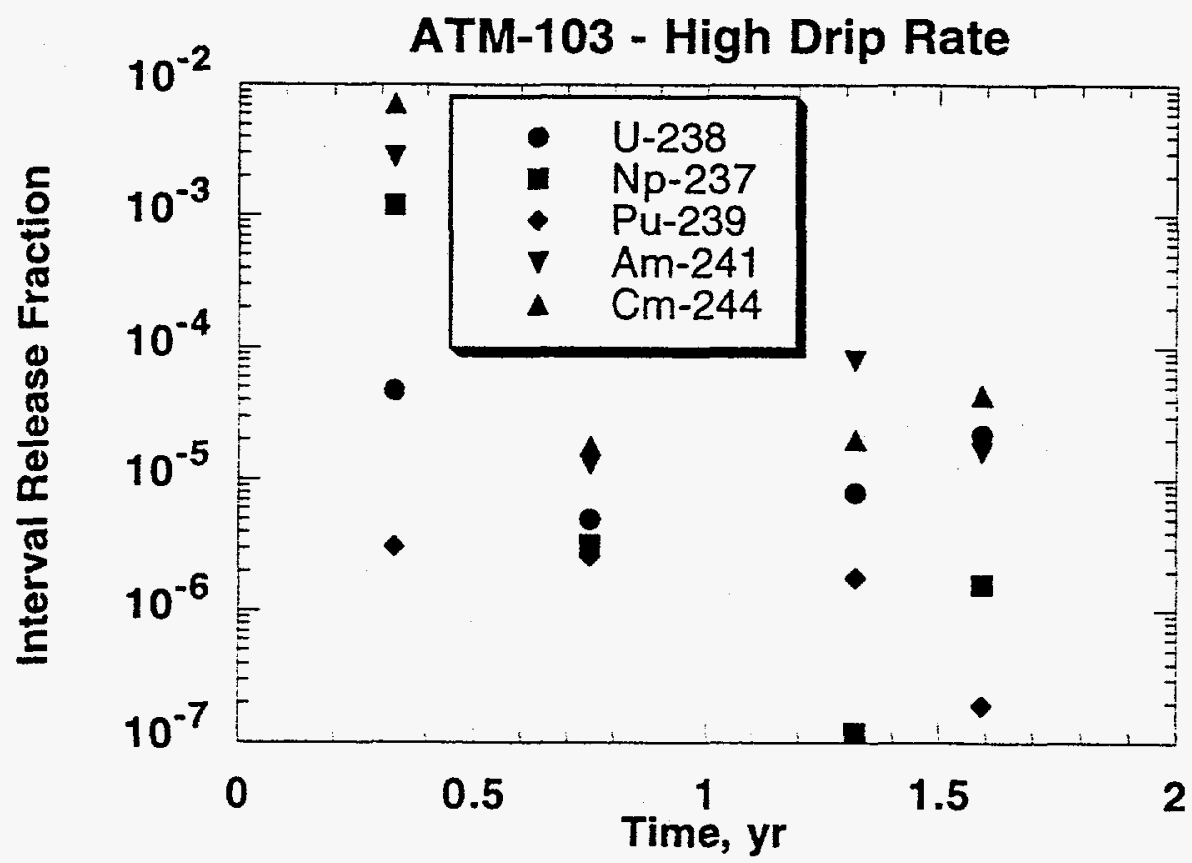

Figure 2. The Actinide Interval Release Fractions for High Drip Rate Test with ATM-103. (The error bars for the actinides are $\pm 50 \%$.) 


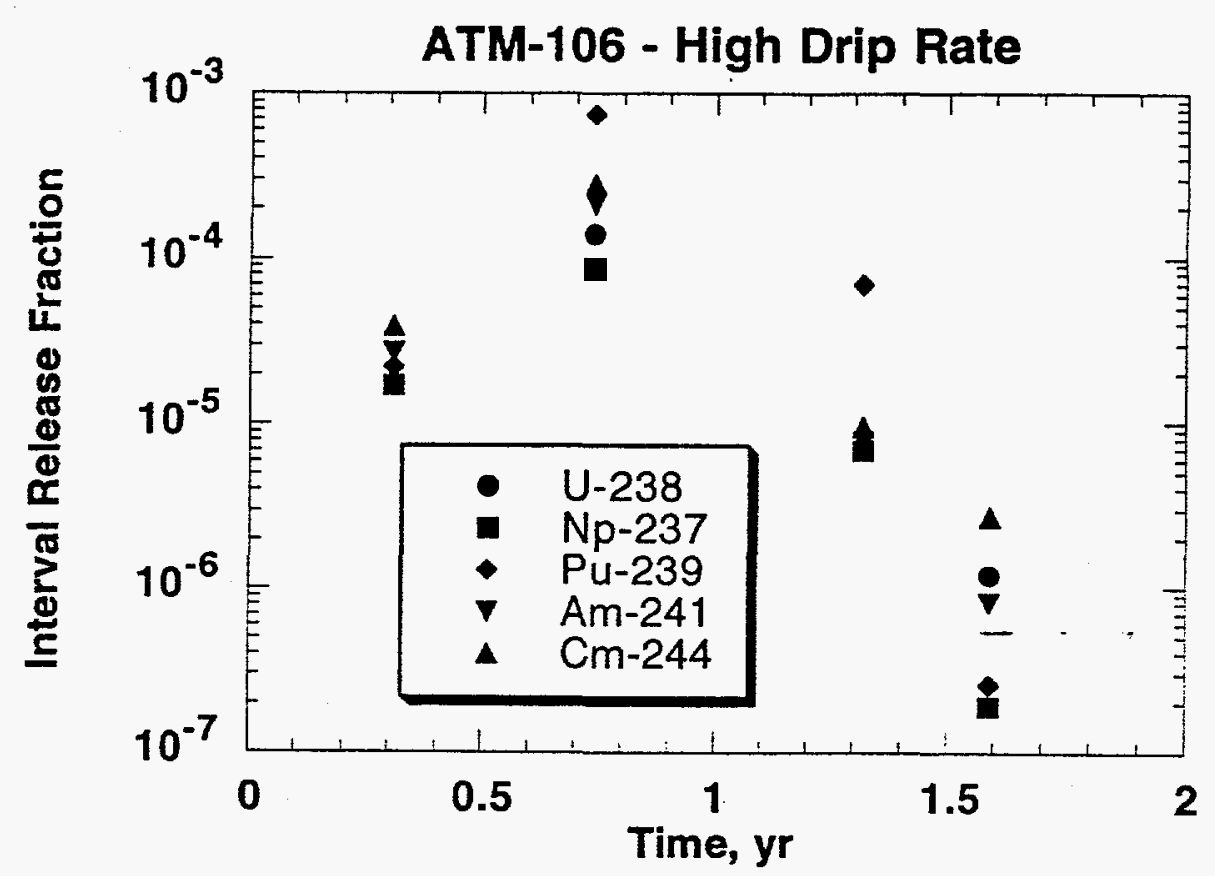

Figure 3. The Actinide Interval Release Fractions for High Drip Rate Test with ATM-106. (The error bars for the actinides are $\pm 50 \%$.)

Table I. Actinide Release Fractions ${ }^{2}$ for High Drip Rate Tests

\begin{tabular}{|c|c|c|c|c|c|}
\hline \multirow[b]{2}{*}{ Species } & \multicolumn{2}{|c|}{ ATM-103 } & \multicolumn{2}{|c|}{ ATM-106 } & \multirow{2}{*}{$\begin{array}{c}\text { Fuel Ratio of } \\
\text { Interval Frac. } \\
106 / 103\end{array}$} \\
\hline & $\begin{array}{c}\text { Interval } \\
\text { Fraction }^{\mathrm{b}} \\
\end{array}$ & Species/U & $\begin{array}{c}\text { Interval } \\
\text { Fraction }^{\mathrm{b}} \\
\end{array}$ & Species/U & \\
\hline${ }^{238} \mathrm{U}$ & $2 \mathrm{E}-5$ & 1 & $1 \mathrm{E}-6$ & 1 & 0.05 \\
\hline${ }^{239} \mathrm{Pu}$ & $2 \mathrm{E}-7$ & 0.01 & $3 \mathrm{E}-8$ & 0.03 & 0.2 \\
\hline${ }^{237} \mathrm{~Np}$ & $2 E-6$ & 0.1 & $2 \mathrm{E}-7$ & 0.2 & 0.1 \\
\hline${ }^{241} \mathrm{Am}$ & $2 \mathrm{E}-5$ & 1 & $8 \mathrm{E}-7$ & 0.7 & 0.05 \\
\hline${ }^{244} \mathrm{Cm}$ & $4 \mathrm{E}-5$ & 2 & $3 E-6$ & 3 & 0.06 \\
\hline \multirow[b]{2}{*}{ Species } & \multicolumn{2}{|c|}{ ATM-103 } & \multicolumn{2}{|c|}{ ATM-106 } & Fuel Ratio of \\
\hline & $\begin{array}{c}\text { Cumulative } \\
\text { Fraction }\end{array}$ & Species/U & $\begin{array}{c}\text { Cumulative } \\
\text { Fraction }\end{array}$ & Species/U & $\begin{array}{c}\text { Cum. Fraction } \\
106 / 103^{c}\end{array}$ \\
\hline${ }^{238} \mathrm{U}$ & $8 E-5$ & 1 & $2 \mathrm{E}-4$ & 1 & 2. \\
\hline${ }^{239} \mathrm{Pu}$ & $8 E-6$ & 0.1 & $1 \mathrm{E}-4$ & 0.5 & 12. \\
\hline${ }^{237} \mathrm{~Np}$ & $1 E-3$ & 12 & $1 E-4$ & 0.5 & 0.1 \\
\hline${ }^{2+1} \mathrm{Am}$ & $3 E-3$ & 36 & $2 E-4$ & 1 & 0.07 \\
\hline${ }^{244} \mathrm{Cm}$ & $7 \mathrm{E}-3$ & 84 & $3 E-4$ & 1.5 & 0.05 \\
\hline
\end{tabular}

${ }^{2}$ Results do not account for material incorporated into alteration products or sorbed on the fuel.

The error bars for the actinides are $\pm 50 \%$.

'Release fraction for the interval between 1.3 and 1.6 years of reaction.

"Ratio of the cumulative fractions for the two fuels for 1.6 years of reaction. 
Table II. ${ }^{137} \mathrm{Cs}$ and Actinide Cumulative Release Fractions ${ }^{\mathrm{ab} b}$ for Unsaturated Tests and "Semistatic" Tests"

\begin{tabular}{|c|c|c|c|c|c|c|c|c|}
\hline \multirow[b]{2}{*}{ Species } & \multicolumn{2}{|c|}{ High Drip Rate } & \multicolumn{2}{|c|}{ Low Drip Rate } & \multicolumn{2}{|c|}{ Vapor } & \multicolumn{2}{|c|}{ Semistatic [9] } \\
\hline & $\begin{array}{c}\text { ATM- } \\
103\end{array}$ & $\begin{array}{c}\text { ATM- } \\
106\end{array}$ & $\begin{array}{c}\text { ATM- } \\
103 \\
\end{array}$ & $\begin{array}{c}\text { ATM- } \\
106\end{array}$ & $\begin{array}{c}\text { ATM- } \\
103 \\
\end{array}$ & $\begin{array}{c}\text { ATM- } \\
106 \\
\end{array}$ & TP & ATM-101 \\
\hline${ }^{238} \mathrm{U}$ & $8 \mathrm{E}-5$ & $2 E-4$ & $2 \mathrm{E}-6$ & $1 E-5$ & $4 E-8$ & $4 \mathrm{E}-7$ & $1 E-4$ & $1 E-4$ \\
\hline${ }^{239} \mathrm{Pu}$ & $8 \mathrm{E}-6$ & $1 \mathrm{E}-4$ & $1 \mathrm{E}-5$ & $2 \mathrm{E}-5$ & $1 \mathrm{E}-7$ & $3 E-7$ & $1 E-4$ & $1 E-4$ \\
\hline${ }^{237} \mathrm{~Np}$ & $1 \mathrm{E}-3$ & $1 \mathrm{E}-4$ & $4 \mathrm{E}-5$ & $6 \mathrm{E}-5$ & $7 \mathrm{E}-7$ & $6 \mathrm{E}-7$ & $1 \mathrm{E}-4$ & $1 E-4$ \\
\hline${ }^{241} \mathrm{Am}$ & $3 E-3$ & $2 E-4$ & $4 \mathrm{E}-4$ & $1 \mathrm{E}-4$ & $3 E-6$ & $7 \mathrm{E}-7$ & $1 \mathrm{E}-4$ & $2 E-4$ \\
\hline${ }^{244} \mathrm{Cm}$ & $7 \mathrm{E}-3$ & $3 E-4$ & $2 E-3$ & $4 \mathrm{E}-4$ & $2 E-5$ & $3 E-6$ & $1 E-4$ & $2 E-4$ \\
\hline${ }^{137} \mathrm{Cs}$ & $2 \mathrm{E}-3$ & $3 E-3$ & $1 \mathrm{E}-5$ & $1 \mathrm{E}-6$ & $7 E-7$ & $4 \mathrm{E}-6$ & $5 \mathrm{E}-3$ & $1 E-2$ \\
\hline
\end{tabular}

${ }^{\mathrm{a}}$ The error bars for ${ }^{137} \mathrm{Cs}$ are $\pm 0.5 \%$. The error bars for the actinides are $\pm 50 \%$. Results do not account for material incorporated into alteration products or sorbed on the fuiel.

${ }^{b}$ These are for fractions for the first 1.6 years of reaction.

'Three cycles ( $460 \mathrm{~d}$ ) at $85^{\circ} \mathrm{C}$ for Turkey Point (TP) fuel , $27(\mathrm{MW} \cdot \mathrm{d}) / \mathrm{kg} \mathrm{U}$ and a fission gas release of $0.3 \%$; and two cycles $(360 \mathrm{~d})$ for ATM-101 fuel, $30(\mathrm{MW} \cdot \mathrm{d}) / \mathrm{kg} \mathrm{U}$ and a fission gas release of $0.2 \%$.

Release fractions for the "semistatic" tests can be compared to those for the high drip rate tests although the comparison is not exact since the conditions for the drip tests were different than those for the "semistatic" tests, including a S/V ratio of $2,240 \mathrm{~m}^{-1}$ for the high drip rate test and $22,400 \mathrm{~m}^{-1}$ for the low drip rate test whereas the "semistatic" tests had a $S / N$ ratio of $70 \mathrm{~m}^{-1}$ for each test cycle. (We assumed that the geometric surface area of the fuel fragments in the "semistatic" tests was comparable to that in the drip tests.). The large S/V ratio in the drip tests would produce a high concentration of radiolysis products [6] at the fuel surface, which may affect fuel reaction, the formation of alteration products, and/or radionuclide release. Despite this, the cumulative release fractions for the ATM-106 fuel, a fuel with a higher burnup and higher gas release than the fuels used by Wilson, were similar to those for the "semistatic" tests. However, the cumulative release fractions for the ATM-103 fuel, which had the same burnup and fission gas release characteristics as the fuels in the "semistatic" tests, were lower for ${ }^{137} \mathrm{Cs},{ }^{238} \mathrm{U}$ and ${ }^{239} \mathrm{Pu}$ and higher for ${ }^{237} \mathrm{~Np},{ }^{241} \mathrm{Am}$, and ${ }^{244} \mathrm{Cm}$ than those reported by Wilson [9]. We do not have sufficient information to account for the differences, so at this time provide them solely for reference.

\section{CONCLUSIONS}

We have focused on release at the 1.3 to 1.6-year test interval to minimize the effect of release from pre-existing oxides on the fuel fragments or radionuclide release associated with the fuel gap. We also examined the transport behavior in the three types of unsaturated tests, which had varying amounts of liquid.

The high drip rate tests appeared to have sufficient liquid to transport dissolved material from the spent fuel to the test vessel, as evidenced by the ${ }^{99} \mathrm{Tc}$ release rates we obtained at the 1.6-year interval [3]. The ${ }^{137} \mathrm{Cs}$ release interval fractions appear to be constant; however, the corresponding release rates are two orders of magnitude smaller than the matrix dissolution rate reported by Gray [8]. This low rate is attributed to the incorporation of cesium into alteration products, which was noted in our tests.

For the high drip rate tests, the ${ }^{238} \mathrm{U}$ interval release fractions were lower than the ${ }^{137} \mathrm{Cs}$ release fractions. For both fuels, the transuranic release fractions were within an order of ten of the ${ }^{238} \mathrm{U}$ release fraction, except for ${ }^{239} \mathrm{Pu}$ release fractions, which were 100 times less. Thus, 
although the transuranics are in solid solution in the uranium matrix, their release is not congruent with uranium's.

For the low drip rate tests, the cumulative release fractions for ${ }^{238} \mathrm{U},{ }^{239} \mathrm{Pu}$, and ${ }^{237} \mathrm{~Np}$ were 10 to 100 times smaller than those for the high drip rate tests while those for ${ }^{241} \mathrm{Am}$ and ${ }^{244} \mathrm{Cm}$ were comparable to those for the high drip rate tests. Since the amount of liquid present was a factor of ten less for the low drip rate tests, this suggests that evaporation was important in these tests which made film transport a potentially important flow pathway for radionuclide release.

Both ${ }^{137} \mathrm{Cs}$ and the actinides were released from the vapor tests; which suggests that the thin water film on the fuel can transport material under the unsaturated conditions of these tests. However, since the cumulative amount of radionuclide transported is 100 times less than that measured in the low drip rate tests, this suggestion needs verification.

\section{ACKNOWLEDGMENTS}

The assistance of Sy Vogler and Jeff Emery is appreciated. This task was performed under the guidance of the Yucca Site Characterization Project (YMP) and ispart of activity D-20-43 in the YMP/Lawrence Livermore National Laboratory Spent Fuel Scientific Investigation Plan. The work was supported by the U.S. Department of Energy, under contract W-31-109-ENG-38.

\section{REFERENCES}

1. R. M. Forester, "Late Glacial to Modern Climate Near Yucca Mountain, Nevada," IHLRWM Proc., ASCE and ANS, 5th Internat. Conf. Las Vegas, Nevada, Vol. 4, 2750-2754 (1994).

2. P. A. Finn et al., "Behavior of Spent Fuel Under Unsaturated Conditions," Proc. of Topical Meeting on DOE Spent Nuclear Fuel, Salt Lake, UT, pp. 421-429 (1994).

3. P. A. Finn et al., "The Release of Actinides, Cesium, Strontium, Technetium, and Iodine from Spent Fuel Under Unsaturated Conditions," presented at Migration 95, Saint-Malo, France, September 10-15, 1995, submitted to Radiochimica Acta.

4. R. J. Guenther et al., Characterization of Spent Fuel Approved Testing Material ATM-103, Pacific Northwest Laboratory Report, PNL-5109-103 (1988).

5. R. J. Guenther et al., Characterization of Spent Fuel Approved Testing Material ATM-106, Pacific Northwest Laboratory Report, PNL-5109-106 (1988).

6. P. A. Finn et al., "Colloidal Products and Actinide Species in Leachate from Spent Nuclear Fuel," Radiochimica Acta 66/67, 189-195 (1994).

7. W. J. Gray et al., "Gap and Grain Boundary Inventories of Cs, Tc, and Sr in Spent LWR Fuel," Mater. Res. Soc. Symp. Proc. 257, 353-360 (1992).

8. W. J. Gray et al., "Parametric Study of LWR Spent Fuel Dissolution Kinetics," J. Nucl. Mater. 190, 46-52 (1992).

9. C. N. Wilson, Results from NNWSI Series 3 Spent Fuel Dissolution Tests, Pacific Northwest Laboratory Report, PNL-7170 (1990). 